\title{
FILANTROPI DAN PENDIDIKAN ISLAM DI INDONESIA
}

\section{Hilman Latief}

Universitas Muhammadiyah Yogyakarta

Jl. Lingkar Barat Tamantirto Bantul Yogyakarta 55183

E-mail: h_latief@yahoo.com

\begin{abstract}
ABSTRAK
Artikel ini berusaha menjawab kemungkinan filantropi Islam bisa memberikan kontribusi terhadap perkembangan pendidikan Islam di Indonesia. Dalam konteks pendidikan Islam di Indonesia, tradisi filantropi terdapat dalam kegiatan wakaf dan sedekah untuk lembaga pendidikan. Untuk itu Dompet Dhuafa mendirikan Lembaga Pengembangan Insan, Rumah Zakat Indonesia merancang Sekolah Juara dan Program Pembibitan Penghafal Al-Qur'an memiliki program BASIQ (Beasiswa Studi Santri Qur'an), EKSPOR (Ekonomi Pesantren Produktif) dan DaquSchool (Darul Qur'an School). Justru lembaga filantropi Islam di Indoensia belum melirik perguruan tinggi Islam sebagai mitra kerja yang utama. Padahal keterlibatan lembaga filantropi Islam untuk mendorong risetriset mutakhir di perguruan tinggi Islam termasuk dalam studi Islam sangat dibutuhkan. sebagai pengimbang dalam pengembangan studi-studi Islam di dunia Barat yang ternyata didanai oleh para filantropis Muslim kelas kakap seperti dari keluarga Bin Laden, keluarga Abbasi dan keluarga kerajaan Saudi.
\end{abstract}

Kata kunci: Aktivisme, Filantropi, Pendidikan Islam.

\section{ABSTRACT}

This article tries to discuss the possibility that Islam philantropy can contribute to the development of education in Indonesia. In the context of Islamic education in Indonesia, the tradition of philantropy can be found in alms and benefaction for educational institution. Therefore, Dompet Duafa established Lembaga Pengembangan Insan Human Resource Development Institution), Rumah Zakat Indonesia designed Sekolah Juara (School for the Champions) and breeding program of reciting Quran had BASIQ program (Scholarship for students who learn Quran), EKSPOR (Productive Economy of Pesantren) and Daqu School (Darul Quran School). These Islamic philantropy institutions had put no concern on Islamic University as main partner yet. Whereas their involvement to support research in university level, specifically regarding Islamic studies, is significantly needed since it provides balance to the development of Islamic studies in the West which is also funded by Muslim philantropists such Bin Laden family and Abassi family and the Saudi Royal family.

Keywords: Activism, Philanthropy, Islamic Education. 


\section{PENDAHULUAN}

Sebagai sebuah gagasan, istilah 'filantropi', yang dalam bahasa Indonesia dimaknai 'kedermawanan' dan 'cinta kasih' terhadap sesama belum terlalu dikenal oleh khalayak luas, meski secara praktis kegiatan filantropi telah menjadi bagian yang tidak terpisahkan dari kehidupan masyarakat Islam Indonesia. Dalam tulisan ini, istilah 'filantropi' merupakan konsep filosofis yang dirumuskan dalam rangka memaknai hubungan antar-manusia dan rasa cinta seseorang atau sekelompok orang kepada sesamanya. Rasa cinta tersebut dieskpresikan diantaranya melalui tradisi berderma atau memberi. Konsep filantropi berhubungan erat dengan rasa kepedulian, solidaritas dan relasi sosial antara orang miskin dan orang kaya, antara yang 'kuat' dan yang 'lemah', antara yang 'beruntung' dan 'tidak beruntung' serta antara yang 'kuasa' dan 'tuna-kuasa'. Dalam perkembangannya, konsep filantropi dimaknai secara lebih luas yakni tidak hanya berhubungan dengan kegiatan berderma itu sendiri melainkan pada bagaimana keefektifan sebuah kegiatan 'memberi', baik material maupun nonmaterial, dapat mendorong perubahan kolektif di masyarakat.

Di kalangan Muslim Indonesia, kegiatan filantropi semakin marak dalam dua dekade ini, terutama pasca krisis moneter di akhir tahun 1990-an. Kegiatan 'islamisasi' yang meningkat dipelbagai sektor, baik dalam birokrasi politik, hukum positif maupun pranata sosial dan budaya masyarakat, memberikan kontribusi terhadap peningkatan aktivitas filantropi Islam. Hal tersebut dapat dicermati dari meningkatnya upaya penggalangan dana masyarakat yang berasal dari zakat dan sedekah (Salim 2008: 115-133; Abidin, 2003). Krisis ekonomi yang ditandai oleh melemahnya nilai tukar mata uang rupiah terhadap dolar, rontoknya dunia perbankan, jatuhnya perusahaan-perusahaan export-import serta meningkatnya angka pengangguran dan kemiskinan telah mendorong sebagian kalangan untuk melirik aktivitas filantropi yang disponsori organisasi-organisasi masyarakat sipil sebagai salah satu solusi alternatif untuk menjaga stabilitas sosial (Fauzia, 2010; Latief, 2012). Didukung oleh kampanye yang masif melalui media cetak dan elektronik dan sosialisasi yang simultan melalui kegiatan-kegiatan keagamaan, para aktivis sosial keagamaan, dengan pelbagai corak dan latar belakang sosial dan ideologi politiknya, mencoba merevitalisasi tradisi filantropi Islam di Indonesia. Latar belakang ideologi-politik dalam konteks ini adalah orientasi sosial-ekonomi dan politik sejumlah lembaga filantropi. Lembagalembaga filantropi Islam di Indonesia didirikan oleh pelbagai kalangan, baik yang berlatar belakang aktivis sosial, partai politik maupun birokrat. Di dalam masyarakat sipil sendiri, lembaga filantropi Islam menjadi bagian penting bagi Islamis 'berhaluan keras' (hardliners dan lebih mengarah pada doktrin/aktivisme filantropi), konservatif maupun organisasi Muslim moderat.

Baik langsung maupun tidak, dunia pendidikan juga menjadi bagian yang tidak terpisahkan dari wacana dan praktik filantropi Islam. Proses birokratisasi dan modernisasi aktivitas filantropi yang semakin menguat dewasa ini adalah konsekuensi dari menguatnya peran kelas menengah Muslim terdidik dalam 
ranah sosial, ekonomi dan politik. Para aktivis masjid kampus tahun 1980-an dan 1990-an telah berperan sebagai aktor-aktor utama dalam membangun dan menghidupkan kembali tradisi filantropi Islam di Indonesia, mulai dari sifatnya yang masih tradisional-konvensional hingga kepada bentuknya yang lebih birokratis dan modern. Pada saat yang sama, konsekuensi lain dari birokratisasi dan modernisasi menyebabkan gerakan/aktivisme filantropi dapat dilihat dari semakin luasnya cakupan kegiatan filantropi yang tidak terbatas pada kegiatan karitatif/berkasih sayang untuk orang miskin tetapi juga sudah terumuskan dalam bentuk 'pelayanan' di pelbagai sektor seperti kesehatan, beasiswa pendidikan, tanggap bencana dan peningkatan ekonomi masyarakat kecil (Latief 2010 dan 2011). Dengan kata lain, terjadi hubungan resiprokal (timbal balik) antara gerakan/aktivisme filantropi dengan dunia pendidikan. Artikel ini bertujuan mendiskusikan dan membahas beberapa isu utama mengenai peran lembaga pendidikan Islam dalam penguatan aktivisme filantropi dan kontribusi kegiatan filantropi dalam memperkuat lembaga pendidikan Islam di Indonesia.

\section{PEMBAHASAN}

\section{Filantropi Islam dan Perubahan Kolektif}

Dinamika filantropi Islam di Indonesia dapat digambarkan dari beberapa periode sejarahnya. Sejak awal abad ke-20, kemunculan organisasi-organisasi Islam baik dalam lingkaran modernis maupun tradisionalis diwarnai oleh pelbagai aktivitas sosial. Pendirian lembaga-lembaga sosial, pendidikan dan kesehatan oleh organisasi keagamaan seperti Muhammadiyah, Persatuan Islam (PERSIS) dan Nahdlatul Ulama (NU) tidak terlepas dari kontribusi material dan non-material dari kaum Muslim, diantaranya melalui penggalangan zakat dan sedekah. Sampai beberapa dekade, gerakan/ aktivisme sosial dan filantropi Islam terus berkembang dan mengalami perubahan, baik pada tataran wacana filosofisnya maupun struktur keorganisasiannya.

Di tingkat akar rumput, terutama di pedesaan (dalam beberapa kasus juga malah di perkotaan), kegiatan filantropi Islam masih dikoordinasikan secara sporadis, dikelola oleh tenaga-tenaga 'non-spesialis' dan model kerja paruh waktu. Masjid-masjid kecil dengan jumlah jamaah yang tidak begitu banyak, juga menggalang dan mengelola dana-dana zakat dan sedekah. Jumlah penggalangan dana yang besarnya tidak seberapa, dikelola dan didistribusikan untuk memenuhi kebutuhan rutin atau untuk kegiatan-kegiatan sosial yang, boleh jadi out put program-nya tidak terencana dengan baik. Target-target perubahan sosial masih jauh dari harapan para pengelola filantropi model ini. Meskipun demikian, aktivitas semacam itu terus mengalir begitu saja, sejak puluhan tahun, hingga kini.

Tren pengelolaan dana dan lembaga filantropi 'tanpa ilmu' seperti di atas, kini tidak lagi menjadi fenomena yang dominan. Perubahan karakter filantropi Islam mulai terlihat saat dipelopori para pengelolanya yang lebih 'terpelajar'. 
Menguatnya kelompok kelas menengah Muslim, didukung oleh kondisi sosial politik yang semakin terbuka pasca pemerintahan Orde Baru yang memberikan ruang bagi aktivis Muslim yang berasal dari kelompok kelas menengah untuk berkiprah, telah membuka peluang bagi munculnya ide-ide baru. Cendikiawan, akademisi, birokrat dan aktivis sosial di kalangan Muslim lebih banyak berinisiatif untuk merumuskan ulang makna filantropi. Kesadaran baru tumbuh bahwa banyak agenda yang harus menjadi bagian dari para pegiat filantropi, terutama berhubungan dengan masalah visi dan akuntabilitasnya. Visi yang dimaksud adalah kemampun merumuskan nilai-nilai keagamaan intrinsik dan progresif yang mampu memberikan dampak perubahan yang diinginkan di masa mendatang. Akuntabilitas yang dimaksud berhubungan dengan strategi implementasi nilai-nilai tersebut melalui pengorganisasian yang terstruktur dan terukur. Akuntabilitas di sini tidak terbatas pada akuntabilitas finansial tetapi juga akuntabilitas nilai, program, sumber daya manusia dan organisasi.

Pada pertengahan tahun 1980-an dan awal 1990-an, beberapa cendikiawan Muslim seperti M. Dawam Rahardjo, M. Amin Aziz, M. Amien Rais dan Masdar F. Mas'udi dikenal publik karena gagasan-gagasan 'maju' mereka dalam perumusan filantropi Islam baik secara konseptual maupun teoretis. M. Dawam Rahardo memiliki peran besar dalam mengenalkan gagasan-gagasan dasar dari ekonomi Islam sementara M. Amin Aziz dikenal sebagai orang yang memiliki perhatian yang penuh terhadap usaha kecil dan menengah. Kedua figur tersebut adalah tokoh dan intelektual Muslim yang aktif di dunia Lembaga Swadaya Masyarakat (LSM). M. Amin Rais dan Masdar F. Mas'udi dikenal dengan gagasannya yang progresif tentang zakat. Usulan mengenai zakat profesi digagas Amin Rais (1987) dan penyetaraan zakat dengan pajak digagas oleh Masdar F. Mas'udi (1993).

Di luar gagasan-gagasan kontroversial pada waktu itu, seperti gagasan tentang zakat produktif, wakaf tunai, zakat profesi serta penyetaraan zakat dengan pajak, beberapa generasi yang lebih muda telah mengambil langkah untuk mematerialisasi wacana filantropi pada tataran praksis, seperti Ery Sudewo dan rekan-rekannya di Republika yang menginisiasi pendirian Dompet Dhu'afa (DD) di Jakarta, 'Abu Syauki' yang mendirikan Dompet Sosial Ummul Qura (DSUQ) atau yang saat ini dikenal dengan Rumah Zakat Indonesia (RZI) di Bandung, atau Abdul Kadir Baraja yang membentuk Yayasan Dana Sosial AlFalah (YDSF) di Surabaya. Di tengah tren dan kecenderungan masyarakat dalam menggiatkan filantropi Islam yang meningkat, beberapa figur dan tokoh keagamaan yang popular seperti Abdullah Gymnastiar, pendiri Pondok Pesantren Daarut Tauhid di Bandung, Yusuf Mansur pendiri Pesantren Daarul Qur'an di Tangerang, telah menjadikan gerakan/aktivisme filantropi sebagai pilar yang menopang kegiatan keagamaan dan pendidikan di lembaga yang mereka pimpin. Sederetan nama dan lembaga lain kini juga melakukan hal yang kurang lebih sama. Beberapa ormas Islam yang telah berdiri sebelumnya seperti Muhammadiyah, PERSIS dan NU, tidak ketinggalan untuk mendirikan lembaga 
khusus pengelola dana filantropi, yaitu Lazismuh (Muhammadiyah), Pusat Zakat Umat (PZU, Persatuan Islam), dan Lazisnu (Lembaga Amil Zakat Nahdlatul Ulama).

Dalam beberapa literatur disebutkan bahwa tujuan dari kegiatan filantropi, saat ini dimaknai sebagai gerakan/upaya menciptakan kebaikan atau kesejahteraan bersama (the public good), dan dampak yang diharapkan dalam sebuah gerakan/aktivisme filantropi dalam pengertian 'kerelawanan' dan 'kedermawanan' adalah terciptanya perubahan kolektif (collective change) dari sebuah komunitas. Meskipun demikian, pentingnya filantropi sebagai sebuah instrumen untuk mendorong perubahan sosial belum begitu disadari oleh masyarakat luas. Robert L. Payton dan Michael P. Moody (2008: 10) bahkan mengilustrasikan bahwa pentingnya filantropi sama pentingnya dengan hukum dan kedokteran. Filantropi merepresentasikan aksi-aksi kolektif masyarakat dan merupakan alat penting dalam upaya kolektif untuk menyelesaikan persoalanpersoalan kehidupan bermasyarakat, seperti pengentasan kemiskinan, perwujudan kesejahteraan publik, pengejawantahan keadilan sosial dan penguatan demokrasi.

Tradisi Muslim di pelbagai belahan dunia boleh jadi belum sampai untuk melekatkan makna filantropi secara luas seperti yang dirumuskan ilmuwan sosial di Barat. Belum banyak rumusan teoretis yang kuat di kalangan masyarakat Muslim untuk menghubungkan konsep zakat, sedekah dan wakaf, dengan gagasan tentang perubahan sosial kolektif (collective social change) atau dengan gagasan tentang kesejahteraan umum (public welfare). Dalam tradisi Islam dikenal

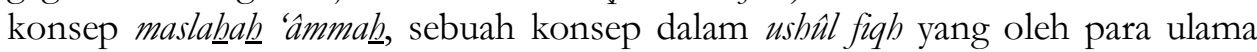
kurang lebih dimaknai sebagai kebaikan bersama, kesejahteraan umum dan bisa juga diartikan ‘kemaslahatan kolektif (Khalid Mas'ud, 1995). Agar menemukan substansi nilai dan dampak praksisnya, wacana filantropi dalam Islam harus dapat berhubungan secara erat dengan tujuan dan esensi syariat Islam (almaqâshid al-syarîab) dalam rangka mendorong kesejahteraan di bidang sosial (ijtimâ'iyyah) maupun ekonomi (iqtishâdiyyah).

Beberapa pertanyaan yang bersifat teoretis-metodologis dapat mendorong pengungkapan makna dan kontribusi lembaga filantropi Islam dalam mendorong perubahan sosial di masyarakat. Kini, lembaga-lembaga filantropi Islam semakin tumbuh subur dan berkembang dalam dua dekade terakhir, baik yang berskala besar, menengah maupun kecil. Meskipun demikian, hal itu tidak berarti bahwa lembaga filantropi sudah berperan optimal dalam memperkuat sistem jaringan pengaman sosial (social security system) di Indonesia. Justru, bila dicermati lebih jauh, tren perkembangan filantropi Islam di Indonesia, setidaknya diukur dari kuantitasnya, belum berbanding lurus dengan diversitas program pemberdayaan masyarakat.

Di antara sekian banyak lembaga filantropi Islam di Indonesia, hanya beberapa lembaga filantropi Islam yang berskala besar saja yang dinilai mampu merumuskan visi dengan baik dan mengimplementasikan programnya secara 
lebih ekspansif. Lembaga-lembaga yang baru berdiri bahkan seringkali hanya merupakan replikasi dari yang sudah ada tanpa ada upaya serius untuk membuat kekhasan, baik dilihat dari karakter organisasinya maupun bentuk program yang dibuatnya. Beberapa lembaga riset seperti PIRAC (Public Interest Research and Advocacy Center) dan CSRC (Center for the Study Religion and Culture-UIN Syarif Hidayatullah) menunjukkan bahwa program dan kegiatan lembaga filantropi Islam tampak lebih didominasi oleh aktivitas karitatif serta pelayanan sosial dibandingkan dengan program yang mempromosikan perubahan struktural.

Sebagai negara Muslim terbesar di dunia dan pada saat yang sama sebagai negara yang plural secara agama dan budaya, lembaga filantropi Islam dihadapkan pada tantangan besar dalam merumuskan konsep perubahan kolektifnya. Pertama adalah bagaimana lembaga filantropi Islam yang sudah ada dan beroperasi di pelbagai daerah dapat mengembangkan program-programnya secara lebih inovatif. Kedua, bagaimana lembaga filantropi Islam beroperasi dalam negara yang plural secara agama dan budaya ini dapat mendefinisikan kelompok-kelompok marjinal yang menjadi target mereka secara baru dan cerdas. Apakah kelompok 'marjinal' itu adalah kaum miskin yang berafiliasi pada agama atau aliran keagamaan tertentu? Apakah kelompok 'marjinal' itu juga dapat mencakup kelompok masyarakat sipil minoritas? Sejauh ini, kelompok masyarakat tertindas dan marjinal belum mendapat penjabaran dan interpetasi yang memadai. Ketiga, bagaimana lembaga filantropi Islam tampil lebih inklusif dan dapat menjaga aksesibilitasnya agar dapat memperkuat barisan masyarakat sipil yang memiliki latar belakang sosial keagamaan yang berbeda-beda.

Dalam konteks ini pendekatan-pendekatan baru perlu dirumuskan oleh lembaga filantropi Islam. Helmut K. Enheier dan Diana Leat (2006) mengatakan bahwa kini diperlukan 'filantropi kreatif (creative philanthropy) yang memadukan 'model pendekatan karitatif (dalam bentuk pelayanan sosial) dengan 'model pendekatan saintifik' (yang berbasis riset dengan target perubahan struktural). Bagaimanapun juga, perubahan sosial membutuhkan pendekatan-pendekatan baru yang seyogyanya dapat dirumuskan dari pelbagai sisi. Penguatan jaringan, kapasitas kelembagaan dan sumberdaya manusia dari lembaga filantropi Islam di Indonesia menjadi tidak dapat dihindarkan dan hal itu membutuhkan dorongan dari -dan bersinergi dengan- lembaga lain, terutama lembaga pendidikan tinggi.

\section{Filantropi Islam dan Akses terhadap Pendidikan}

Disadari atau tidak, awal perkembangan dan penyebaran lembaga pendidikan Islam di Indonesia, mulai dari pesantren, madrasah dan sekolah hingga perguruan tinggi tidak bisa dilepaskan dari kegiatan filantropi. Salah satu bentuk kontribusi yang paling dominan dari masyarakat sipil terhadap pendirian lembaga-lembaga sosial dan pendidikan adalah kegiatan wakaf, yaitu penyerahan aset berupa lahan atau bangunan dari seseorang atau sebuah keluarga (waqif) untuk dikelola oleh seseorang atau lembaga (nadzir). Praktik wakaf atau dalam bahasa Inggris sering diistilahkan 'pious endowment' memiliki usia ribuan tahun 
bahkan dipraktikan sebelum zaman Islam. Dengan kata lain, wakaf adalah praktik kedermawanan yang juga dipraktikan dalam tradisi dan budaya lain di luar tradisi Islam. Berbeda dengan tradisi kedermawanan lainnya, wakaf mensyaratkan 'keabadian' harta yang diserahkan untuk dikelola dan tidak bisa digunakan secara konsumtif sampai habis. Bukan harta wakaf itu sendiri yang digunakan, melainkan hasil pengelolaan harta wakaf itu yang kemudian dimanfaatkan oleh pengelola wakaf untuk pelbagai kegiatan sosial. Pada masa pra kemerdekaan, kuatnya praktik wakaf, berupa penyerahan aset lahan dan bangunan untuk dijadikan tempat ibadah dan belajar di kalangan Muslim, telah menstimulasi pemerintah kolonial Belanda membuat regulasi khusus tentang wakaf (Fauzia, 2010, Salim 2003). Pesantren, masjid, rumah miskin, panti asuhan dan klinik yang dikelola oleh ormas-ormas Islam dan organisasi masyarakat sipil banyak yang bertumpu pada praktik wakaf (Bamuallim dan Irfan Abu Bakar, 2005).

Menilik perkembangan sejarah Islam modern, khususnya pada awal abad keduapuluh, bisa diketahui bahwa peran wakaf sangat penting dalam perkembangan lembaga-lembaga pendidikan yang dikelola oleh ormas-ormas Islam. Muhammadiyah, Persatuan Islam (PERSIS), Nahdlatul Ulama dan ormasormas lainnya seperti al-Irsyad dan Mathla'ul Anwar adalah beberapa organisasi masyarakat yang lembaga-lembaga pendidikannya didukung oleh gerakan/aktivisme wakaf. Selain mendirikan lembaga pendidikan, ormas-ormas Islam juga mendirikan lembaga sosial yang khusus dalam menangani anak-anak dari kalangan keluarga miskin, yakni dengan mendirikan panti-panti asuhan sosial. Dengan kata lain, gagasan pendirian lembaga pendidikan adalah bagian integral dari perspektif kaum Muslim dalam memberikan solusi terhadap masalah sosial masyarakat, termasuk untuk pengentasan kemiskinan. Dalam hubungannya dengan ini, kemiskinan dapat diartikan sebagai ketidakmampuan seseorang atau sebuah keluarga dalam memberikan fasilitas pendidikan dan kesehatan yang memadai, selain ketidakmampuan menyediakan kebutuhan dasar sandang, pangan dan papan. Karena itu kegiatan/gerakan/aktivisme filantropi pada umumnya difokuskan pada penyediaan layanan pendidikan dan kesehatan selain pemberiaan bahan kebutuhan pokok (makanan) kepada orang-orang yang membutuhkannya.

Menghubungkan antara kemiskinan, gerakan filantropi dengan pendidikan bukan hanya terjadi di dunia Islam. Hal yang sama justru lebih banyak terjadi di Negara-negara Eropa, terutama pada abad ke enam belas sampai delapan belas ketika gagasan mendirikan lembaga pendidikan oleh gereja-gereja seiring dan sejalan dengan pendirian panti-panti asuhan sosial. Dalam Jurnal Paedagogica Historica, Juliane Jacobi, dari Universität Potsdam, Jerman, menulis sebuah artikel yang membahas hubungan antara filantropi dan pendidikan yang didasarkan pada latar sosial di Eropa pada abad ke enambelas sampai delapan belas. Pada masa-masa itu, beberapa kalangan di Eropa, khususnya para 'pendidik dan dokter yang tercerahkan' (enlightened educators and medical doctors) mencoba 
merumuskan model alternatif untuk memelihara anak-anak dari kalangan miskin dan yatim piatu di sebuah tempat yang tersentralisasi yang disebut dengan panti asuhan. Pada masa itu, anak-anak yatim piatu dan keluarga miskin dididik dalam sebuah panti asuhan agar mereka bisa bekerja untuk membantu kalangan kelas menengah. Tujuan penyelenggaraan pendidikan di panti asuhan waktu itu adalah menyiapkan sebuah angkatan yang terdiri atas anak-anak yatim piatu yang produktif. Lembaga pendidikan waktu itu berdekatan dengan tempat-tempat kerja, seperti pasar maupun industri-industri kecil. Namun, pada abad ke delapan belas Eropa menyaksikan proses transisi model 'pengentasan' kemiskinan yang dilakukan oleh kalangan kelas menengah yang tidak lagi semata mendidik anakanak miskin melalui panti asuhan untuk mempekerjakan mereka, tetapi juga penyediaan pendidikan agar anak-anak bisa belajar di sekolah dan menjadi anakanak yang terpelajar (Juliane Jacobi, 2009: 62).

Di Indonesia, gerakan/aktivisme modernis Muhammadiyah awal abad keduapuluh yang kurang lebih melakukan hal yang serupa dengan apa yang dilakukan oleh gereja-gereja atau ordonansi Kristen yang ada pada waktu itu, berperan besar dalam mendirikan sejumlah lembaga pendidikan dan panti asuhan. Muhammadiyah saat ini telah mengelola ribuan amal usaha dalam bentuk sekolah, mulai tingkat taman kanak-kanak sampai ke perguruan tinggi (Latief, 2010: 191-210; Fuad, 2004: 410-414). Kiai Ahmad Dahlan, pendiri Muhammadiyah, memiliki perhatian mendalam terhadap kemiskinan dan 'keterbelakangan' masyarakat Muslim, baik dilihat dari sosial, ekonomi terutama pendidikan. Pendidikan untuk kaum Muslim masih dikelola secara tradisional dan berada di tempat-tempat terpencil di bawah pengelolaan kiai-kiai lokal. Di wilayah perkotaan, akses terhadap lembaga pendidikan juga terbatas untuk kalangan ningrat dan kolonial, sehingga anak-anak miskin lebih banyak yang hidup di jalanan. Karena itu, pendirian panti-panti asuhan yang didirkan oleh Kiai Dahlan dengan organisasi Muhammadiyahnya kurang lebih memiliki inspirasi yang sama, yaitu menampung anak-anak miskin untuk dipelihara dan dididik agar memiliki masa depan yang lebih baik. Melalui gerakan filantropi yang didukung oleh masyarakat, terutama yang menjadi simpatisan gerakan modernis, sekolah-sekolah formal Islam kemudian didirikan untuk memberikan akses pendidikan yang luas.

Pesantren-pesantren yang dikelola oleh kiai-kiai di daerah, khususnya pedesaan, pun memiliki peran besar dalam memberikan akses terhadap pendidikan. Kegiatan pengajian yang dipimpin para pemuka agama di desa-desa setidaknya menjadi modal sosial yang kuat untuk mendorong keterlibatan masyarakat dalam mendirikan lembaga pendidikan Islam. Figur seorang kiai yang dihormati, bukan saja telah menjadi daya tarik bagi anggota masyarakat melainkan juga menarik minat perusahaan-perusahaan swasta untuk menyumbangkan sebagian harta benda dan berpartisipasi dalam pengembangan lembaga pendidikan Islam. Pesantren Gontor-Ponorogo, Tebuireng-Jombang dan Lirboyo-Kediri di Jawa Timur, Pesantren As-Salam-Surakarta, Darunnajah 
dan Yayasan Pendidikan Al-Azhar di Jakarta, Pesantren Al-Zaytun di Indramayu dan Pesantren Cipasung di Tasikamalaya-Jawa Barat, adalah beberapa contoh dari ribuan pesantren di Indonesia yang sudah menggunakan dana-dana filantropi secara cukup besar dalam pengembangan lembaga pendidikannya (Latief, 2011: 50-71).

Dewasa ini, kegiatan filantropi sudah dikelola semakin modern, dengan model penggalangan dana dan pengelolaan yang lebih canggih. Beberapa lembaga filantropi Islam yang cukup besar di Indonesia, seperti Dompet Dhuafa, Rumah Zakat Indonesia, serta yayasan-yayasan yang dikelola figur-figur yang popular juga menjadikan pendidikan Islam sebagai salah satu prioritas program mereka. Ustadz Yusuf Mansur, seorang da'i muda yang identik dengan gerakan berderma, telah menjadi ikon baru dalam pengembangan pendidikan Islam alternatif untuk kalangan yang tidak mampu. Tentu saja, model-model pendidikan Islam yang ditawarkan oleh lembaga-lembaga filantropi Islam saat ini beraneka ragam dan memiliki kekhasan masing-masing.

\section{Dompet Dhuafa: SMART Ekselensia Indonesia}

Dompet Dhuafa (DD) didirikan pada tahun 1993 oleh beberapa orang wartawan yang bekerja dalam Harian Umum Republika, sebuah koran yang didirikan oleh para pegiat yang tergabung dalam Ikatan Cendekiawan Muslim Indonesia (ICMI). Tampil sebagai 'Koran Islam', Dompet Dhuafa memberikan warna baru dunia media masa di Indonesia yang sebelumnya belum banyak yang dianggap dapat merepresentasikan Islam. Dalam usianya yang menginjak dua dasawarsa (1993-2013), DD berkembang menjadi lembaga amil zakat yang disegani dan mampu tampil sebagai model lembaga filantropi Islam modern di Indonesia. Program-programnya sangat beragam dan kelola dengan dinamis dan profesional, baik di bidang sosial, ekonomi, kesehatan maupun pendidikan. Sebagai sebuah lembaga filantropi, DD mengelola pelbagai jenis lembaga, misalnya, koperasi, BMT, pendanaan usaha-usaha kecil dan pemberdayaan petani dan nelayan. Dalam beberapa tahun terakhir DD juga melirik pengembangan model pendidikan alternatif secara lebih serius melalui salah satu 'lembaga sayap' atau 'jejaring' yang bernama (Lembaga Pengembangan Insani-LPI).

LPI dibentuk untuk mengelola isu-isu pendidikan. Tujuan dari pendirian lembaga itu adalah agar lembaga amil zakat seperti DD dapat memberikan kontribusi yang lebih nyata, terencana, sistematis dan memiliki dampak yang lebih terukur dalam proses pengentasan kemiskinan. Terdapat beberapa program yang saat ini dikelola LPI-DD, yaitu: 1) Makmal Pendidikan, 2) SMART Ekselensia Indonesia, 3) Sekolah Guru Ekselensia Indonesia, dan 4) School Social Responsibility. Dengan beberapa program tersebut, LPI-DD dapat memberikan beasiswa untuk anak-anak dari kalangan tidak mampu dan memproyeksikan mereka untuk menjadi orang-orang yang berprestasi tinggi. Dengan demikian, DD mengharapkan bahwa kontribusi mereka dalam pengembangan pendidikan di Indoensia bisa lebih terukur. 
SMART Ekselensia Indonesia (SMART-EI) adalah sebuah program yang dibuat untuk memberikan kesempatan kepada anak-anak lulusan SD yang memiliki potensi untuk berprestasi namun berasal dari kalangan tidak mampu untuk menikmati jenjang pendidikan yang lebih tinggi. Sebagai sebuah lembaga amil zakat yang banyak bekerja dan berhubungan dengan orang-orang dari kalangan tidak mampu dan dengan orang-orang yang kaya yang menjadi penyumbang, DD menawarkan model pendidikan akseleratif untuk pendidikan menengah selama 5 tahun. Seolah-olah DD menawarkan sekolah yang agak elit namun para peserta didiknya justru dari kalangan yang kurang mampu secara ekonomi. Dalam laman resminya dituliskan: "SMART EI didedikasikan untuk anak-anak dhu'afa berprestasi dari seluruh Indonesia. Sekolah ini digagas untuk meningkatkan harkat dan martabat kaum dhu'afa melalui program pendidikan dan pembinaan yang komprehensif dan berkesinambungan. Diharapkan setelah melalui proses pendidikan dan pembinaan di SMART EI, setiap siswa siap berkarya bagi diri, keluarga, bangsa dan agamanya."

Sebagai lembaga pendidikan yang relatif baru, SMART EI telah mendidik sekitar 236 anak yang berasal dari 27 provinsi sejak tahun 2008. Siswa dididik secara intensif dan tinggal di asrama yang disedikan di sekolah. Selama dalam masa pendidikan, dari awal sampai akhir, peserta didik dibebaskan dari biaya. Program untuk pelajar dari kalangan keluarga miskin ini dikombinasikan dengan program untuk pengembangan kualitas guru yang disebut Sekolah Guru Ekselensia Indonesia (SGKI) dan program Makmal Pendidikan (MP). Kedua program tersebut yaitu SKGI dan MP dirancang untuk pengembangan kualitas guru baik yang berada di dalam maupun di luar program SMART-EI. DD memberikan pelatihan bagaimana menjadi guru yang berkualitas dan berprestasi juga bagaimana mengelola sekolah secara lebih profesional. Program lain dari DD adalah School Social Responsibility (SSR), yaitu sinergi sekolah dan elemen masyarakat dengan LPI-DD dalam bentuk penggalangan kontribusi (materi dan non materi) untuk mewujudkan Sekolah Desa Produktif sebagai pusat revitalisasi desa. Dengan demikian, perspektif yang dirumuskan oleh DD tentang relasi antara filantropi Islam dengan pengembangannya tidak terbatas pada penguatan proses belajar mengajar melainkan juga bagaimana sebuah lembaga filantropi dan lembaga pendidikan yang dimilikinya dapat memberikan kontribusi yang lebih besar terhadap pemberdayaan masyarakat secara lebih luas termasuk di desadesa.

Meskipun dalam model kampanye, diksi-diksi yang digunakan serta program-program yang dicanangkan, tidak terlalu kental dengan numenklatur Islam, namun tidak bisa dipungkiri bahwa konsep-konsep keislaman yang diusung oleh DD telah dirumuskan menjadi agenda-agenda sosial yang lebih terbuka. Apalagi para donator DD serta aktivis yang terlibat di dalamnya memiliki latar belakang yang berbeda-beda, baik yang berafiliasi kepada tradisi keislaman kaum modernis maupun kepada tradisionalis. Lembaga pendidikan yang didirikan pun tidak lepas dari nuansa Islam. Selain ditujukan untuk 
memberikan pengetahuan di bidang sains, anak-anak yang tergabung dalam program SMART-EI diberikan pengetahuan agama serta kemampuan untuk menghafal al-Qur'an dan bahasa asing (Arab dan Inggris). Dengan kata lain, melalui SMART-EI ini, DD hendak mencetak calon-calon sarjana Muslim yang berasal dari keluarga kurang mampu agar menjadi sosok pemimpin Muslim masa depan.

\section{Rumah Zakat Indonesia: Sekolah Dasar Juara}

Model lain pengembangan lembaga pendidikan Islam yang dipelopori oleh lembaga amil zakat adalah program 'Sekolah Juara' dari Rumah Zakat Indonesia (RZI). Lembaga amil zakat yang bermarkas di Bandung ini sudah beroperasi sejak tahun 1998, yang pada awal berdirinya masih bernama Dompet Sosial Ummul Qura (DSUQ). Lembaga ini didirikan oleh Abu Syauqi, seorang ustadz dan aktivis Muslim di Bandung. Konsep program yang ditawarkan oleh RZI sebagai sebuah lembaga amil zakat adalah Intergrated Community Development (ICD). Konsep ini terbagi menjadi empat wilayah program yaitu EduCare untuk pendidikan, HealthCare untuk kesehatan, YouthCare untuk kepemudaan, dan EcoCare untuk pemberdayaan ekonomi (Latief, 2010; dan www.rumahzakat.org.)

Salah satu bentuk kegiatan dari program EduCare adalah Sekolah Juara, yaitu sebuah program yang ditujukan untuk "memberikan pendidikan gratis dan berkualitas bagi masyarakat yang membutuhkan.” Tidak seperti SPART-EI milik DD yang lebih mengutamkan pendidikan tingkat menengah (SMP-SMA), Sekolah Juara milik RZI dirancang untuk memberikan pendidikan sekolah dasar dan menengah (SD-SMP). Sekolah Juara dibentuk dengan mengembangkan konsep "multiple intelligences" guna memberikan kepada siswa kesempatan menggali potensi yang dimiliki mereka. Pelajar yang tergabung dalam Sekolah Juara adalah anak-anak yatim atau dari kalangan kurang mampu, namun memiliki prestasi dan kemampuan yang perlu dikembangkan.

Untuk pengelolaan Sekolah Juara ini, RZI menyediakan beasiswa, seragam, buku-buku pelajaran, sarana dan prasarana, serta menyelenggarakan kegiatan belajar mengajar yang didanai oleh sumbangan masyarakat. Dalam rancangan RZI, satu tahun biaya investasi yang harus dikeluarkan sekitar Rp. 2,200,000,000 untuk SD Juara, dan Rp. 2.650.000.000 untuk SMP Juara. Program-program pendidikan lainnya mencakup beasiswa dan penyelenggaraan Pendidikan Anak Usia Dini (PAUD) dan sejak tahun 2003 sampai 2012, penerima manfaat RZI di bidang pendidikan berjumlah 1,241,898 orang.

Jumlah Penerima Manfaat EduCare-RZI 2012

\begin{tabular}{|c|l|r|r|}
\hline No & \multicolumn{1}{|c|}{ Jenis Program } & $\begin{array}{c}\text { Jumlah Penerima } \\
\text { Manfaat 2012 }\end{array}$ & $\begin{array}{c}\text { Jumlah Penerima } \\
\text { Manfaat 2003-2012 }\end{array}$ \\
\hline 1 & Beasiswa Ceria & 428,596 & 698,222 \\
\hline 2 & Beasiswa Juara & 2,550 & 2,550 \\
\hline 3 & Pengembangan Potensi Anak & 13,454 & 27,218 \\
\hline 4 & Sekolah Juara & 141,440 & 165,943 \\
\hline
\end{tabular}




\begin{tabular}{|c|l|r|r|}
\hline No & \multicolumn{1}{|c|}{ Jenis Program } & $\begin{array}{c}\text { Jumlah Penerima } \\
\text { Manfaat 2012 }\end{array}$ & $\begin{array}{c}\text { Jumlah Penerima } \\
\text { Manfaat 2003-2012 }\end{array}$ \\
\hline 5 & Gizi Sang Juara & 9,840 & 10,388 \\
\hline 6 & Lab Juara & 1,322 & 1,322 \\
\hline 7 & Mobil Juara & 26,672 & 39,772 \\
\hline 8 & Kemah Juara & 2,703 & 26,808 \\
\hline 9 & Bantuan Langsung Pendidikan & 355 & 4,940 \\
\hline 10 & EduCare non Program & 4,325 & 6,112 \\
\hline 11 & PAD & 10,752 & 19,021 \\
\hline & TOTAL (SENYUM JUARA) & 642,009 & $1,241,898$ \\
\hline
\end{tabular}

Sumber: Majalah Rumah Lentera-RZI, No.74, Tahun 8 (Februari 2013).

Untuk mencapai target yang telah ditentukan, khususnya dalam masalah pendanaan, RZI bekerjasama dengan perusahaan-perusahaan yang beroperasi di Indonesia, baik perusahaan dalam negeri swasta, BUMN, maupun perusahaan asing. Saat ini RZI mengelola 11 SD Juara di pelbagai kota, yaitu 2 di kota Bandung dan Cimahi-Jawa Barat, 4 sekolah di Jakarta, 1 sekolah masing-masing di Semarang, Yogyakarta, Pekanbaru, Surabaya dan Medan; serta 2 SMP Juara di Bandung dan Pekanbaru.

\section{PPPA Darul Qur'an}

PPPA adalah Program Pembibitan Penghafal Al-Qur'an yang dipelopori oleh Ustadz Yusuf Mansur. Tidak seperti halnya lembaga amil zakat yang lain, yang menawarkan model pendidikan konvensional kendati dengan sentuhan yang mengedepankan service excellence untuk siswa-siswa yang berasal dari kalangan keluarga tidak mampu, PPPA lebih fokus pada pendidikan agama Islam, khususnya penghafalan al-Qur'an. Yusuf Mansur sendiri membina karirnya sebagai juru dakwah atau da'i yang isu-isu ceramahnya terkait dengan praktik filantropi Islam. Tema-tema tentang pahala dan manfaat bersedekah, keihklasan dan ketulusan serta pengabdian diri kepada Tuhan melalui praktik 'memberi' kepada sesama, menjadi tema utama dalam ceramah-ceramahnya.

Sebagaimana da'i-da'i kondang yang lain yang kerap muncul di media televisi, Yusuf Mansur juga mendirikan lembaga sosial dan keagamaan yang bergerak di bidang pelatihan spiritual, majelis taklim dan pendidikan agama Islam. Sebelum mendirikan PPPA, Yusuf Mansur dikenal sebagai pendiri 'Wisata Hati', sebuah lembaga training keislaman. Kemudian gerakan dakwah Yusuf Mansur terlihat menjadi lebih khas setelah mengampanyekan sedekah dan mendirikan PPPA, sebuah yayasan yang difokuskan untuk mencetak para pengahafal al-Qur'an di Indonesia. Dalam perjalanannya, PPPA memiliki beberapa peran, yaitu sebagai lembaga sosial dan filantropi Islam serta lembaga dakwah Islam yang secara khusus mendorong terbentuknya kader-kader hâfidz (penghafal al-Qur'an) di Indonesia. Salah satu bentuk program pendidikan PPPA adalah didirikannya Pesantren Tahfizh al-Qur'an di pelbagai daerah serta penyelenggaran model-model alternatif pembelajaran dan penghafalan al-Qur'an. 
PPA memiliki program yang beragam seperti BASIQ (Beasiswa Study Santri Qur'an), EKSPOR (Ekonomi Pesantren Produktif) dan DaquSchool (Darul Qur'an School) yang terintregrasikan dengan Pesantren Tahfiz Al-Qur'an. Kehadiran lembaga filantropi dan dakwah seperti PPPA, telah mendorong perkembangan jumlah dan model madrasah-madrasah Islam yang saat ini berkembang di Indonesia. Hal ini mengisyaratkan bahwa gerakan filantropi Islam telah membawa dampak pertumbuhan lembaga-lembaga keislaman di Indoensia dalam satu dasawarsa terakhir, terutama di bidang pendidikan.

\section{Filantropi dan Pendidikan Tinggi Islam}

Meksipun pendidikan tinggi Islam memiliki misi dakwah namun pendidikan tinggi Islam memiliki karakteristik tidak hanya memberikan pendidikan dalam pengertian memberikan hard skill melainkan juga soft skill. Pendidikan tinggi Islam di Indonesia saat ini berperan sebagai lembaga-lembaga penelitian yang dituntut untuk berkontribusi dalam proses pencerdasan bangsa di dunia akademik. Di Indonesia, pada umumnya terdapat dua karakteristik pendidikan tinggi Islam yaitu, Perguruan Tinggi Negeri dalam bentuk Universitas Islam Negeri (UIN), Institut Agama Islam Negeri (IAIN) yang dikelompokan sebagai Perguruan Tinggi Islam Negeri (PTAIN) dan seluruhnya berada di bawah kewenangan Kementerian Agama (Kemenag). Karena Indonesia masih menganut pendidikan 'dua atap' bahkan lebih, beberapa Perguruan Tinggi Swasta (PTS) berada di bawah binaan Kementerian Pendidikan dan Kebudayaan, seperti Universitas-universitas Muhammadiyah se-Indonesia, Universitas Islam Indonesia (UII), Universitas Islam Bandung (UNISBA), Universitas Islam Nusantara (UNINUS) dan Universitas Islam Malang (UNISMA) berada dalam naungan Kemendikbud, kecuali fakultas agama Islam yang ada di universitas tersebut, berada dalam naungan Kemenag.

Keterlibatan negara yang begitu (sangat) kuat dalam penyelenggaraan pendidikan Islam di Indonesia, memberikan beberapa konsekuensi. Pertama, perkembangan Pendidikan Tinggi Islam di Indonesia berjalan begitu cepat. Jumlah UIN, IAIN, PTAIN/PTAIS, bertambah dari waktu ke waktu, bahkan hampir setiap tahun. Negara, melalui Kementerian Agama, mengeluarkan dana yang begitu besar untuk penguatan kualitas perguruan tinggi Islam dan pendirian Perguruan Tinggi Islam yang baru. Konsekuensi yang kedua adalah lembagalembaga filantropi Islam belum melirik perguruan tinggi sebagai mitra kerja yang utama. Setidaknya, keterlibatan lembaga filantropi Islam untuk mendorong risetriset mutakhir di perguruan tinggi masih belum begitu besar termasuk dalam studi Islam. Pada saat yang sama, Perguruan Tinggi Islam pun belum memaksimalkan eksistensi lembaga filantropi sebagai rekan kerja mereka dalam pengembangan studi-studi Islam. Hal ini justru berbeda dengan yang terjadi di dunia Barat, di mana semakin banyak filantropis yang menginvestasikan dana mereka untuk pengembangan studi Islam di perguruan tinggi. 
Di Eropa maupun Amerika, praktik 'wakaf untuk lembaga pendidikan ternyata sangat kuat. Kampus-kampus besar seperti Harvard, Oxford dan Cambridge adalah contoh lembaga pendidikan Tinggi di negara-negara maju yang masih bertumpu pada 'tradisi wakaf dari para filantropis. Ketika studi tentang keislaman menguat di lembaga pendidikan tinggi di Barat, tidak sedikit para filantropis Muslim menjadi donator utama pusat-pusat studi Islam, melalui skema 'endowment. Oxford Centre for Islamic Studies (OXCIS) menjalankan programprogram risetnya dengan dukungan dari keluarga Bin Laden. Stanford University di Amerika membuka pusat studi Islam (The Sobaib and Sara Abbasi Program in Islamic Studies) atas dukungan Keluarga Abbasi, sebuah keluarga pengusaha Muslim Pakistan-Amerika yang bergerak di bidang jasa teknologi informasi. Pusat studi Islam di Cambridge mendapat dukungan dana penuh dari keluarga kerajaan Saudi (Alwaleed bin Talal Foundation). Itulah sebabnya pusat-pusat studi Islam di Barat berkembang dengan cepat dan semakin kuat karena didukung oleh filantropis-filantropis kelas kakap.

Bagaimana kontribusi lembaga pendidikan dalam penguatan tradisi filantropi Islam di Indonesia? Pertanyaan tersebut penting untuk dikemukakan guna mengelaborasi lebih jauh peran lembaga pendidikan tinggi dalam penguatan masyarakat sipil dan demokrasi serta penguatan wacana dan praktik filantropi Islam di Indoensia. Dalam perspektif yang lebih luas, lembaga filantropi Islam maupun lembaga pendidikan tinggi memiliki tujuan yang selaras yaitu memperkuat peran masyarakat sipil dalam mendorong terciptanya kesejahteraan umum dan memperkuat jejaring pengaman sosial. Oleh karena itu hubungan resiprokal antara lembaga pendidikan tinggi dan lembaga filantropi untuk penguatan wacana dan praktik filantropi Islam di Indonesia perlu dirumuskan dengan beberapa alasan.

Pertama, sebagai sebuah nilai, filantropi Islam masih perlu mendapatkan perhatian lebih banyak, tidak hanya di kalangan praktisi Muslim tetapi juga di kalangan akademisi. Seperti halnya ketika lembaga pendidikan mengajarkan kewarganegaraan (civic education) sebagai nilai-nilai intrinsik kebangsaan, maka konsep kedermawanan dan voluntarisme dapat dikatakan sebagai nilai instrinsik agama yang perlu rekonseptualisasi secara lebih operasional dan perlu didiseminasikan ke masyarakat luas. Perguruan Tinggi Islam sesungguhnya dapat berperan sebagai 'motor penggerak' untuk merumuskan konsep-konsep social entrepreneurship yang lebih canggih melalui riset-riset yang lebih serius.

Kedua, dalam perspektif perkembangan wacana keislaman, para ulama fikih di Indonesia belum memberikan respons yang memadai terhadap perubahan sosial yang terjadi dalam masyarakat akar rumput. Karena itu, produk-produk hukum Islam di Indonesia sering kali tidak cepat mengadaptasi diri dengan kebutuhan nyata masyarakat. Pandangan-pandangan fikih Islam yang bersifat hitam-putih (clear-cut) seperti yang dirumuskan oleh otoritas keagamaan, baru merespons aspek-aspek 'legal' tentang boleh tidaknya dan halal-haramnya sesuatu. Para cendekiawan Muslim dan kaum terdidik yang berada dalam dunia 
pendidikan, setidaknya bisa mengimbangi kelambanan merumuskan produk hukum Islam melalui ijtihad-ijtihad baru yang berbasis riset, termasuk ijtihadijtihad kolektif-akademik yang berhubungan dengan produk hukum di bidang filantropi Islam.

Ketiga, pusat-pusat studi dan penelitian di lembaga pendidikan tinggi yang memiliki alat analisis dan instrumen intelektual yang lebih sistematis, dapat mengambil peran dalam mengidenfikasi problem-problem sosial masyarakat, seperti kemiskinan, kesenjangan sosial, keadilan dan kesetaraan gender, akses ekonomi dan pelayanan kesehatan untuk masyarakat kecil. Lembaga pendidikan tinggi juga dapat memberikan kontribusi yang bersifat teoretis dalam merumuskan pendekatan solutif yang tepat untuk mengatasi persoalan-persoalan tersebut.

Sebagai perbandingan, beberapa perguruan tinggi di negara-negara maju sudah mencoba membangun pusat-pusat studi dengan fokus kajian tentang filantropi, sebut saja misalnya, Centre on Wealth Pbilanthropy (Boston College), The Centre on Pbilanthropy and Public Policy (University of Shouthern California), Centre for the Study of Philanthropy (City University of New York) dan The Centre of Philanthropy (Indiana University). Bercermin dari mereka, bukan mustahil bahwa lembaga pendidikan tinggi Islam, baik yang negeri (UIN, IAIN, STAIN) maupun swasta (Muhammadiyah, NU dan yayasan Islam lainnya) dapat menggeluti secara serius kajian filantropi Islam. Bagaimanapun juga, secara teoretis maupun praksis, sebagai lembaga yang memiliki 'core business' pengembangan ilmu pengetahuan, perguruan tinggi Islam memiliki kepentingan dan kapasitas untuk mengembangkan filantropi Islam ke arah yang lebih baik.

\section{SIMPULAN}

Istilah 'filantropi' (kedermawanan dan cinta kasih) terhadap sesama belum terlalu dikenal oleh khalayak luas namun sebenarnya secara praksis kegiatan filantropi telah menjadi bagian yang tidak terpisahkan dari kehidupan masyarakat Islam Indonesia. Untuk menghubungkan konsep zakat, sedekah dan wakaf dengan gagasan filantropi, dalam tradisi Islam dapat digunakan konsep maslabah ámmah, kebaikan bersama, kesejahteraan umum atau 'kemaslahatan kolektif. Sejak awal abad ke-20, pendirian lembaga-lembaga sosial, pendidikan dan kesehatan oleh organisasi keagamaan seperti Muhammadiyah, Persatuan Islam (PERSIS) dan Nahdlatul Ulama (NU) tidak terlepas dari gerakan/aktivisme filantropis. Kini, wacana dan gerakan filantropi di Indonesia terinisiasi dalam beberapa lembaga zakat seperti Dompet Dhu'afa (DD) di Jakarta, Dompet Sosial Ummul Qura (DSUQ) atau Rumah Zakat Indonesia (RZI) di Bandung, dan Yayasan Dana Sosial Al-Falah (YDSF) di Surabaya. Dalam konteks pendidikan Islam di Indonesia, tradisi filantropi terdapat dalam kegiatan wakaf, yaitu penyerahan aset berupa lahan atau bangunan dari seseorang atau sebuah keluarga (wâqif) untuk dikelola oleh seseorang atau lembaga (nadrîr) pendidikan. Abdullah Gymnastiar dan Yusuf Mansur pun telah menjadikan 
gerakan/aktivisme filantropi sebagai pilar yang menopang kegiatan pendidikan di lembaganya. Lembaga Pengembangan Insan-DD telah memprogramkan pilantropi-pendidikan melalui: 1) Makmal Pendidikan, 2) SMART Ekselensia Indonesia, 3) Sekolah Guru Ekselensia Indonesia, dan 4) School Social Responsibility. Program tersebut berupa pemberian beasiswa untuk anak-anak dari kalangan tidak mampu dan memproyeksikan mereka untuk menjadi orang-orang yang berprestasi tinggi. RZI merancang Sekolah Juara guna menyediakan beasiswa, seragam, buku-buku pelajaran, sarana dan prasarana serta menyelenggarakan kegiatan belajar mengajar bagi anak yaatim-piatu dan kurang mampu dengan didanai oleh sumbangan masyarakat. Hingga saat ini, penerima manfaat RZI di bidang pendidikan berjumlah 1,241,898 orang. PPA memiliki program BASIQ (Beasiswa Study Santri Qur'an), EKSPOR (Ekonomi Pesantren Produktif) dan DaquSchool (Darul Qur'an School) yang terintregrasikan dengan Pesantren Tahfiz Al-Qur'an. Kehadiran lembaga filantropi dan dakwah seperti PPPA, telah mendorong perkembangan jumlah dan model madrasah-madrasah Islam yang saat ini berkembang di Indonesia. Justru lembaga filantropi Islam di Indonesia belum melirik perguruan tinggi Islam sebagai mitra kerja yang utama. Padahal keterlibatan lembaga filantropi Islam untuk mendorong riset-riset mutakhir di perguruan tinggi Islam termasuk dalam studi Islam sangat dibutuhkan sebagai pengimbang dalam pengembangan studi-studi Islam di dunia Barat yang ternyata didanai oleh para filantropis Muslim kelas kakap seperti dari keluarga Bin Laden, keluarga Abbasi dan keluarga kerajaan Saudi.

\section{DAFTAR PUSTAKA}

Abidin, Hamid (ed.). 2003. Sumbangan Sosial Perusabaan:Profil dan Pola Distribusinya di Indonesia, Survey 226 Perusabaan di 10 Kota. Jakarta: Piramedia, PIRAC \& Ford Foundation. Jacobi.

Bamuallim, Chaider, S. dan Abu Bakar, Irfan (eds.). 2005. Filantropi Islam dan Keadilan Sosial: Studi Kasus Lembaga Wakaf dan Zakat di Indonesia. Jakarta: Center for the Study of Religion and Culture (CSRC), UIN Syarif Hidayatullah.

Bamuallim, Chaider, S. et al (ed.). 2006. Islamic Pbilanthropy \& Social Development in Contemporary Indonesia. Jakarta: CRCS UIN Syarif Hidayatullah.

Bamuallim, Chaider, S and Irfan Abubakar (eds.). 2005. Revitalisasi Filantropi Islam: Studi Kasus Lembaga Wakaf dan Zakat di Indonesia . Jakarta: Center for the Study of Religion and Culture (CSRC), UIN Syarif Hidayatullah.

Enheier, Helmut K. and Leat, Diana. 2006. Creative Philanthropy: Toward a New Philanthropy for the Twenty-First Century. London and New York: Roudledge.

Fauzia, Amelia. (ed.). 2006. Filantropi untuk Keadilan Sosial: Studi tentang Potensi, tradisi dan Pemanfaatan Filantropi Islam di Indonesia. Jakarta: Center for the Study of Religion and Culture (CSRC), UIN Syarif Hidayatullah. Fuad, 
Muhammad. 2004. "Islam, Modernity and Muhammadiyah's Educational Programme," Inter-Asia Cultural Studies, Volume 5, Number 3, 400-414.

Jacobi, Juliane. 2009. Paedagogica Historica. "Between charity and education: orphans and orphanages in early modern times," Vol. 45, Nos. 1-2, February-April, 51-66.

Latief, Hilman. 2010. Melayani Umat: Filantropi Islam dan Ideologi Kesejabteraan Kaum Modernis. Jakarta: Gramedia.

Latief, Hilman. 2010. "Health Provision for the Poor: Islamic Aid and the Rise of Charitable Clinics in Indonesia," Journal of Southeast Asia Research, 18, 3 (September), 503-553.

Latief, Hilman. 2012. "Islam and Humanitarian Affairs in Indonesia: the Middle Class and New Patterns of Social Activism," in Kees van Dijk and Jajat Burhanuddin (eds.), Islam in Indonesia: Contrasting Images and Interpretations (Amsterdam: Amsterdam University Press-ICAS, 2012).

Latief, Hilman. "Filantropi Islam dan Aktivisme Sosial Berbasis Pesantren," Afkearuna: Jurnal Ilmu-ilmu Keislaman, Vol.8 No.1 (Januari - Juni), 50-71.

Mas'ud, Muhammad Khalid. 1995. Shatibi's Philosophy of Islamic Law. Kuala Lumpur: Islamic Book Trust.

Mas'udi, Masdar F. 1993. Agama Keadilan: Risalab Zakat (Pajak) dalam Islam. Jakarta: P3M.

Payton, Robert L. and Michael P. Moody. 2008. Understanding Philanthropy: Its Meaning and Mission. Bloomington and Indianapolis: Indiana University Press.

Salim, Arskal. 2008. The Shift in Zakat Practice in Indonesia: From Piety to an Islamic Socio-Political-Economic System. Chiang Mai: Asian Muslim Action Network and Silkworm Books.

Salim, Arskal. 2003. "Zakeat Administration in Politics of Indonesia," in Arskal Salim and Azyumardi Azra, Shari'a and Politics in Modern Indonesia. Singapore: ISEAS.

Shihab, Alwi. 1995. "The Muhammadiyah Movement and Its Controversy with Christian Mission in Indonesia", PhD Dissertation, Temple University, Philadelphia, Pennsylvania. 